\title{
Order of the Cities: Usage as a Transportation Economic Parameter
}

\author{
Zsombor Szabón ${ }^{*}$, Árpád Török², Tibor Sipos ${ }^{1}$ \\ ${ }^{1}$ Department of Transport Technology and Economics, Faculty of Transportation Engineering and Vehicle Engineering, \\ Budapest University of Technology and Economics, H-1521 Budapest, P.O.B. 91, Hungary \\ 2 Department of Automotive Technologies, Faculty of Transportation Engineering and Vehicle Engineering, \\ Budapest University of Technology and Economics, H-1521 Budapest, P.O.B. 91, Hungary \\ *Corresponding author, e-mail: szabo.zsombor@mail.bme.hu
}

Received: 25 January 2019, Accepted: 09 April 2019, Published online: 14 November 2019

\begin{abstract}
On one hand, better and better databases occur through the world, however for cities a lot of important data is unavailable. On the other hand, the cities are one of the most important units, where transportation interactions ought to be analyzed. In this recent paper the order of the cities (based upon the NUTS - Nomenclature des unités territoriales statistiques classification) will be introduced, and an answer will be found for the question whether this parameter could be used as a substitution of an economic parameter.
\end{abstract}

Keywords

transportation geography, transportation economics, urban public transport

\section{Introduction}

In case of comparing cities to each other, for example in a linear regression model, it can be useful, if something about the economy could be told. The main problem with this, that there are not any useable data for it. In the Eurostat database, there are a few data about cities, however providing data is voluntary. In this recent article a simplified variable will be shown, which can substitute the real economy data.

\section{Background}

If talking about cities is in progress, then it is quite important how to apply a bound for them. On one hand, Friedman (2007) mentioned, that the cities and the surrounding regions should be treated together, however on the other hand it is quite difficult to find out the proper surrounding region. However, on the other hand there are cities which can be analyzed without their surroundings. Beaverstock et al. (1999) analyzed 50+ cities around the world and compared them in order to set up an inventory for world cities. For example, Taylor and Hoyler (2000) stated, that in some approaches 'London is so exceptional that it can be argued to be not a European city but related much more to New York than to the UK or Europe' (Herrschel and Newman, 2002).
In the transportation related researches numerous papers compare cities to each other (e.g. Klingeret al., 2013; Fellesson and Friman, 2008), and in this kind of comparisons this parameter could be helpful.

In order to measure the efficiency of the introduced economy parameter the urban public transportation seems to be the best to use. The case of public transportation is special in a way that the users, beyond their money, also pay by their time. And as more public transport is produced, the invested time will decrease due to the increased frequencies, better coverage and more direct routes (Preston, 2015). Because of this a hypothesis was set up that a wider choice of routes to users will lead to a greater role for public transport in cities (Scheurer and Porta, 2006). If this kind of wide choice is need to be operated a large amount of subsidies is need to be given by the operating city government, as the public transport cost become too high, the usage would decrease, (Nilsson, 2015) however expanding urban population requires this kind of service as well (Murray et al., 1998; Török and Schmalz, 2018). Because of this fact, a hypothesis could be set up, that there is a dependence between the welfare of the city and the operated public transport system. Comparing public 
transportation systems is widely used in the transportation science (e.g. Sienkiewicz and Hołyst, 2005; Pucher and Kurth, 1995).

If public transportation is taken into account, it is important to find some method in order to analyze efficiency. In general, a literature review was written where the ways of the measurement of one of the most important parameter of the public transport systems were introduced (Saif et al., 2019). In case of Budapest Gaal et. al (2014) analyzed the performance of the public transport system. Pina and Torres (2001) found out a DEA analysis where the Catalonian cities were taken into consideration. Murray et al. (1998) and Murray (2001) measure this kind of efficiency through the accessibility in greater Brisbane region. Another approach is the fractal analysis, which was set up for Seoul's subway and railway network to measure efficiency (Kim et al., 2003). For a metro system an analysis was published which tries to measure the efficiency based upon the network of Xi'an (Zhang et al., 2017). The limitations of the public bus service efficiency were analyzed on the example of Putrajaya, Malaysia (Borhan et al., 2019).

Besides, there are numerous papers analyzing cities' public transportation system, which will be part of our analysis too. Gumz and Török (2015) analyzed Budakeszi's (HU) public transportation system as well during their four-step model. Yatskiv et al. (2017) in their paper analyzed Riga's (LT) public transportation, from the accessibility approach. Also an accessibility analysis was set up for the city of Sisak (HR), and surroundings (Šipuš and Abramović, 2017). Analysis for Zagreb (HR), and surroundings was also set up (Dadić et al., 2001; Matulin et al., 2014).

\section{Method}

\subsection{Setup of the variable}

As it was mentioned before the goal of this recent paper is to find a variable, which could be proper for using as an indicator of the cities' economy. This indicator should be the order of the cities. The order in short words is a number between 0 and 5, and indicates the highest NUTS (Nomenclature des unités territoriales statistiques) territory whose capital is the actual city (case 1) (European Parliament, 2003). For example, all of the national capitals will get 0 as their orders, because the largest NUTS territory whose capital are they is the actual country (NUTS0).

Because these kind of approach could be misleading, some corrections should be set up. First, there are cities which have additional roles, for example in the life of the
European Union. A good example for this is Frankfurt am Main, which is only a capital of a district (NUTS3), however it is one of the most important cities in the European Union. So these cities order should be set to 0 (case 2). Another important thing is, that if Germany is taken into consideration, a lot of changes were introduced in the regionalization politics after 2000, so these changes need to be taken into consideration in the modified order (case 3). The number of cities in each order is shown by Fig. $1(N=421)$.

The third approach is, besides, that there is difference between the size of the countries, which is taken into consideration in the NUTS system. So, in case of capitals the order will stand for the lowest NUTS level which is still represents the whole country.

It is need to be taken into consideration, that there are not exist a complete NUTS classification for all of the countries, so in that cases only estimation is feasible.

\subsection{Proof of the usability}

\subsubsection{Case of Hungary}

The goal of the recent paper is to prove, that these order can be used instead of economic indicators, in case of transportation economic researches. In order to prove, let's take into consideration some transport economic indicators. These could be the number of the private cars, and the number of the public transport (PT) lines.

If Hungary is taken into consideration, these kind of data could be accessed easily from the webpage of the PT operators, and the Hungarian Central Statistical Office (KSH, 2018a; 2018b). In Hungary 137 settlements could

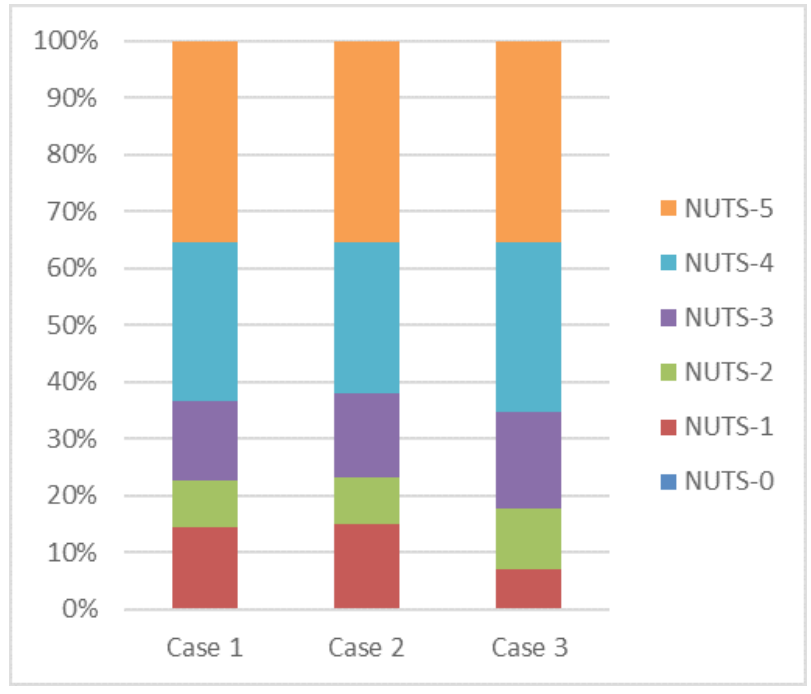

Fig. 1 The ratio of the different ordered settlements according to the different cases (Source: authors) 
be taken into consideration. In case, only the number of the PT lines is taken into consideration the strength of the dependency is 0.4755 in case of linear regression, and 0.559 in case of exponential regression, as it can be seen on Fig. 2.

However, if the number of the passenger cars is also taken into consideration, then, the next linear regression model could be set up (additional calculations have been shown that the exponential regression model is not better) (*** stands for the $p<0.001$ ).

As it can be seen in Table 1, the model is quite good, with an acceptable R-square value. The tests for the model acceptance are also quite good, their significance level is nearly 0 in all of the cases (Bolla and Krámli, 2005).

However, it is need to be taken into consideration, that this kind of regression model cannot be taken into consideration properly because the number of PT lines and the number of passenger cars are not dependent $\left(R^{2}=0.9234\right)$ from each other. Besides, due to the regional system of Hungary, the NUTS- 1 capitals are missing from the analysis. So, it is advised to take into consideration the other European countries too.

Table 1 The result of the regression model (Source: authors)

\begin{tabular}{lccc}
\hline & Coefficients & t value & \\
\hline Intercept & 4.4242 & 84.0902 & $* * *$ \\
Number of PT lines & -0.0535 & -10.2709 & $* * *$ \\
Number of passenger cars & $2.2921 \mathrm{e}-05$ & 6.9809 & $* * *$ \\
\hline F statistics & & 107.2028 & $* * *$ \\
R-square & & 0.6154 & \\
\hline
\end{tabular}

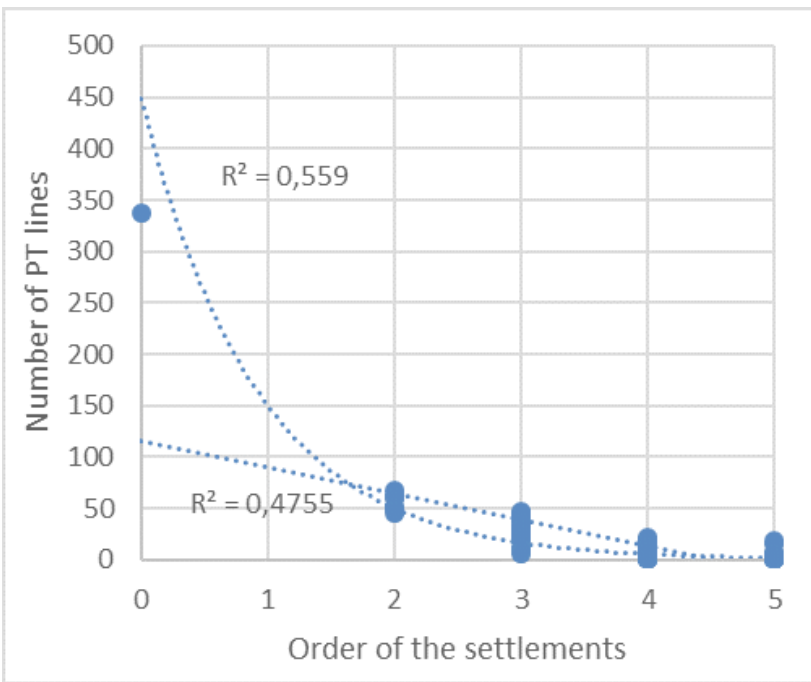

Fig. 2 The dependence between the order, and the number of the PT lines in case of Hungary (Source: authors)

\subsubsection{Case of Europe}

Before introducing the models to prove our theory, the analysis of the goals is necessary. If the order of the cities is favored to use instead of the actual economy parameter, it is ought to be proven, that the order explain the economy parameter, and not vice versa.

In case of Europe, 421 settlements from almost all of the European countries were analyzed in order to prove the statement. A similar model would be accepted to find, but because the number of PT lines and the number of passenger cars are not dependent from each other, then only the number of the PT lines is taken into consideration.

Calculations shown that there is a chance, that the dependence between the order and the number of the PT lines occurs because of the population. So, the effect of the population should be eliminated. In order to eliminate, a linear regression model is need to be set up to calculate the number of the PT lines explained by the population. After that if the rate of the two parameters are analyzed than it will be independent from the population.

\section{Results}

As it was mentioned before, there are three ways to take into consideration the order. In general, it can be said, that with the newer cases, the dependence based upon the values are better. $(0.5278,0.5412$ and 0.6505 respectively) Note, that the distanced elements on the diagram are Moscow, London, Stockholm (respectively), and Saint Petersburg (as NUTS-1 capital). The relation between the order and the number of PT lines, in the third case, where the $R^{2}$ is the highest can be observed in Fig. 3.

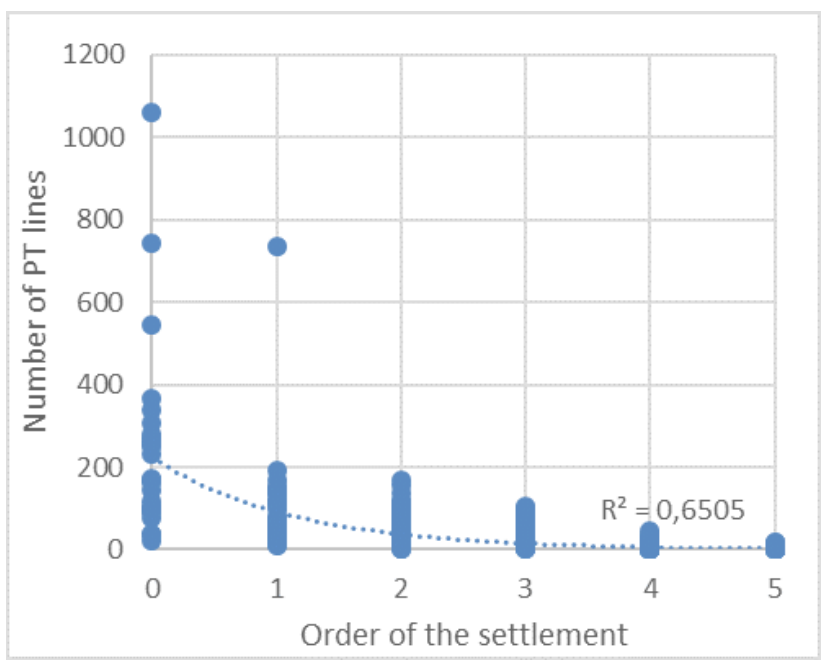

Fig. 3 The dependence between the order, and the number of the PT lines in case of Europe in case 3 (Source: authors) 
However, it must be note, that there is a dependence between the order and the population $\left(R^{2}=0.8264\right)$ so, there is a chance that the dependence between the order and the number of the PT lines can only be observed because the dependence between the population, and the number of PT lines exists.

So, as it was mentioned before, it is advised to eliminate the effect of the population from the number of the PT lines. In order to do this a linear model was set up, in order to calculate the number of the PT lines based upon the population. The results of the model can be observed in Table $2(* * *$ stands for the $p<0.001)$.

Based upon this model, a number of PT lines can be calculated, which is only the consequence of the population. Regarding, a ratio also can be calculated, which is the ratio of the actual, and the estimated number of the PT lines. If this ratio is taken into consideration, this is also can be thought as a transportation economic parameter, however it is free from the effect of the population. The diagram of this ratio can be seen on Fig. 4.

As a result, it can be said that this parameter can be used as an economic parameter of the given settlement. The shown diagram is valid only for case 3 , for case 1 and case 2 , the $R^{2}$ values are 0.366 and 0.3779 respectively.

\section{Validation}

In case of validation, the next question is given. The orders of the settlements are same in case of Western and Eastern Europe too. So the question is given, whether could a better parameter be created based upon the regional GDP numbers. Two parameters are calculated, the first is the GDP/ capita, the other is the estimated settlement GDP, which is the multiplication of the GDP/capita, and the population of the actual settlement, assuming that the given region is homogenous. Both of the parameters are calculated from data of 2015 based upon the database of the Eurostat and the World Bank (Eurostat, 2016a; 2016b; World Bank, 2018).

If the GDP/capita data is taken into consideration, the next diagram (Fig. 5) will be concluded. As it can be seen, no trend line could be fitted on the points.

Table 2 The model for estimating the number of PT lines based upon the population (Source: authors)

\begin{tabular}{lccc}
\hline & Coefficients & \multicolumn{2}{c}{ t value } \\
\hline Intercept & 17.8244 & 9.2587 & $* * *$ \\
Number of PT lines & $9.2988 \mathrm{e}-05$ & 44.6590 & $* * *$ \\
F statistics & 1994.4231 & & $* * *$ \\
R-square & 0.8264 & & \\
\hline
\end{tabular}

If the settlement GDP is taken into consideration better dependencies will occur, similar to the level of the dependence based upon the $R^{2}$ values. This state is shown by Fig. 6.

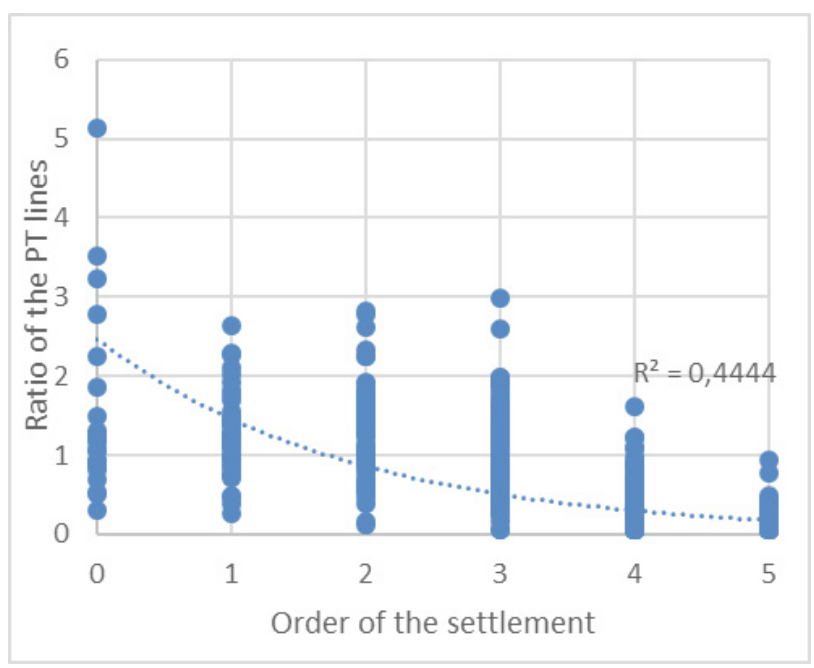

Fig. 4 The dependence between the ratio and the order (Source: authors)

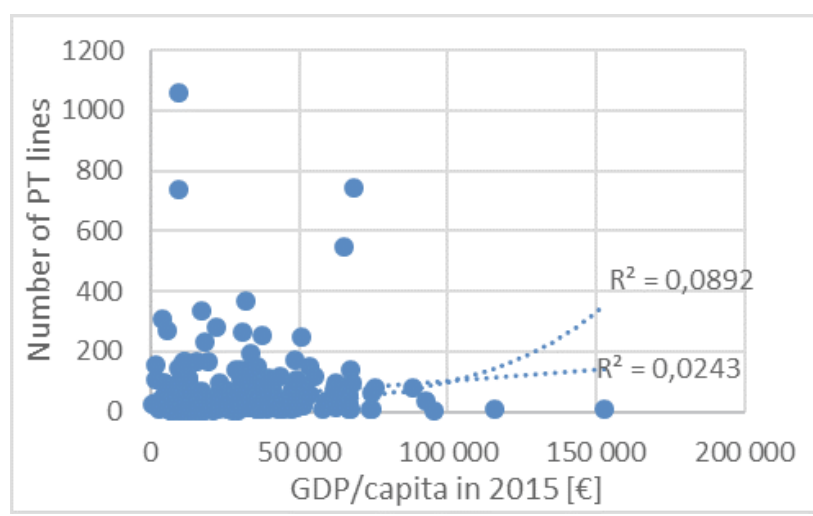

Fig. 5 The dependence between the GDP/capita and the number of PT lines (Source: authors)

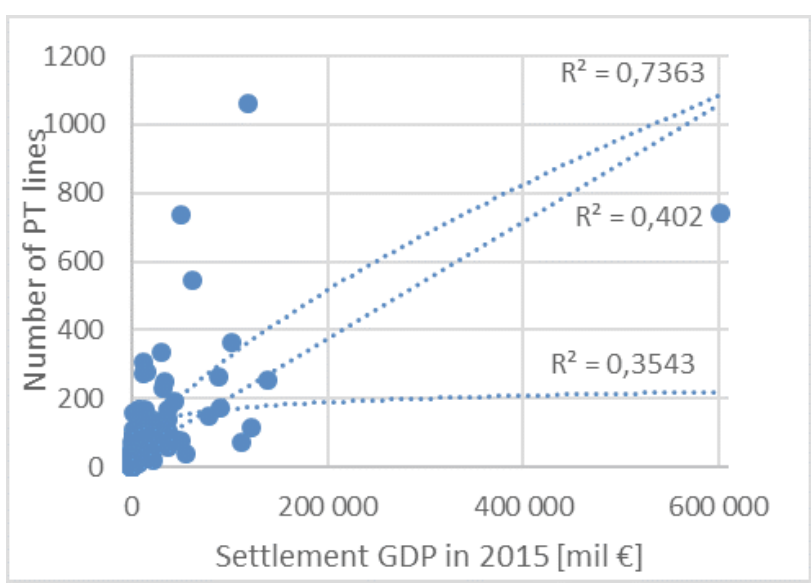

Fig. 6 The dependence between the settlement GDP and the number of the PT lines (Source: authors) 
It is need to be mentioned, that the dependence between the estimated settlement GDP and the population is not so strong $\left(R^{2}=0.5315\right)$, however in order to measure the parameters the ratio also should be analyzed in this case as well. If the ratio of the PT lines is taken into consideration, the next diagram (Fig. 7) will occur.

Based upon everything, the estimated settlement GDP provides better dependence, however it is hard to find proper data, even in Europe too. Besides the use of the order is better in case of measuring cities, because this estimation is based on regional GDP, regional and settlement population, which can be also important dependent variables.

\section{Conclusion}

As a conclusion it can be stated, that a simple substitution parameter is found for economy data. After manage all of the occurring problems a parameter has been set up, which is as strong as the estimated settlement GDP - in case assuming homogeneity in the given region.

However, some criticism about this method is need to be mentioned. First, the sampling was arbitrary, during the choice of the analyzed cities none of the sampling rules/ methods were taken into consideration.

\section{References}

Beaverstock, J. V., Smith, R. G., Taylor, P. J. (1999) "A roster of world cities", Cities, 16(6), pp. 445-458.

https://doi.org/10.1016/S0264-2751(99)00042-6

Bolla, M., Krámli, A. (2005) "Statisztikai következtetések elmélete" (Theory of statistical inference), 2nd ed., Typotex Kft., Budapest, Hungary. (in Hungarian)

Borhan, M. N., Ibrahim, A. N. H., Syamsunur, D., Rahmat, R. A. (2019) "Why Public Bus is a Less Attractive Mode of Transport: A Case Study of Putrajaya, Malaysia", Periodica Polytechnica Transportation Engineering, 47(1), pp. 82-90. https://doi.org/10.3311/PPtr.9228

Dadić, I., Štefančić, G., Rajsman, M. (2001) "Zagrebačka County and the City of Zagreb as the Centre of the Croatian Transport System", Promet-Traffic-Traffico, 13(suppl. 4), pp. 17-24.

European Parliament Regulation (EC) (2003) "No 1059/2003 26 May 2003 on the establishment of a common classification of territorial units for statistics (NUTS)"

Eurostat (2016a) "Regional gross domestic product by NUTS 2 regions - million EUR" [online] Available at: http://ec.europa.eu/eurostat/

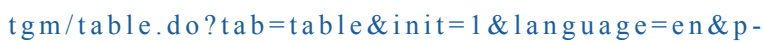
code $=\operatorname{tgs} 00003 \&$ plugin $=1$ [Accessed: 29 April 2019]

Eurostat (2016b) "Population on 1 January by NUTS 2 region" [online] Available at: http://ec.europa.eu/eurostat/tgm/table. do? tab $=$ table $\&$ init $=1 \&$ language $=$ en $\&$ pcode $=\operatorname{tgs} 00096 \&$ plugin $=1$ [Accessed: 29 April 2019]
Second, the number of the PT lines is not the best parameter to describe the network of the given settlement. It is obvious, that a metro line is not equal with a bus line, so a more precise summarize should be created in the future.

Third, bounds of cities was quite hard to find out, and from this, it was difficult to find out which routes belong to the actual city, and which do not.

However, our goal, which was finding a proper parameter instead of the economy data was successful, it can be stated that the order is a feasible parameter.

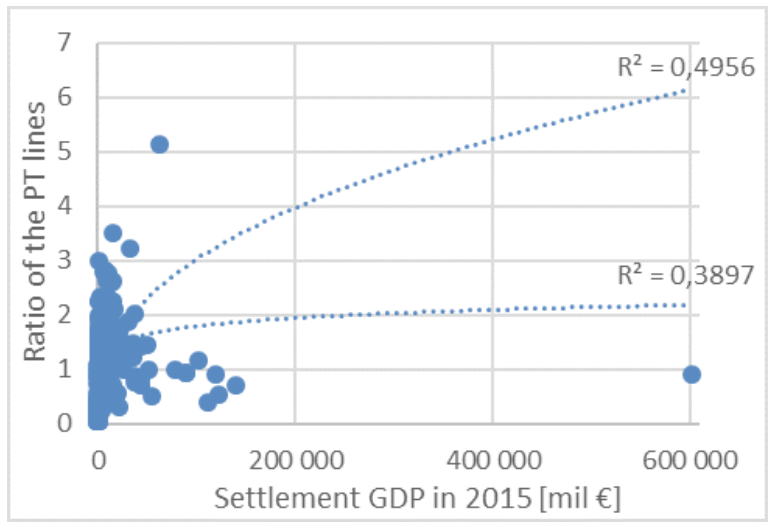

Fig. 7 The dependence between the settlement GDP and the ratio of the PT lines (Source: authors)

Fellesson, M., Friman, M. (2008) "Perceived satisfaction with public transport service in nine European cities", Journal of the Transportation Research Forum, 47(3), pp. 93-103. https://doi.org/10.5399/osu/jtrf.47.3.2126

Friedmann, J. (2007) "The Wealth of Cities: Towards an Assets-based Development of Newly Urbanizing Regions", Development and Change, 38(6), pp. 987-998.

https://doi.org/10.1111/j.1467-7660.2007.00461.x

Gaal, Gy., Horváth, E., Török, Á., Csete, M. (2014) "Analysis of Public Transport Performance in Budapest, Hungary", Periodica Polytechnica Social and Management Sciences, 23(1), pp. 68-72. https://doi.org/10.3311/PPso.7724

Gumz, F., Török, Á. (2015) "Investigation of cordon pricing in Budakeszi", Periodica Polytechnica Transportation Engineering, 43(2), pp. 92-97. https://doi.org/10.3311/PPtr.7579

Herrschel, T., Newman, P. (2002) "Governance of Europe's City Regions: Planning, Policy and Politics", 1st ed., Routledge, London, United Kingdom.

https://doi.org/10.4324/9780203446683

Kim, K. S., Benguigui, L., Marinov, M. (2003) "The fractal structure of Seoul's public transportation system", Cities, 20(1), pp. 31-39. https://doi.org/10.1016/S0264-2751(02)00094-X

Klinger, T., Kenworthy, J. R., Lanzendorf, M. (2013) "Dimensions of urban mobility cultures-a comparison of German cities", Journal of Transport Geography, 31, pp. 18-29. https://doi.org/10.1016/j.jtrangeo.2013.05.002 
KSH (2018a) "Személygépjármű ezer lakosra 2013. 12 31." (Number of passenger cars for 1000 inhabitants in 2013. 12. 31.) [online] Available at: http://www.ksh.hu/interaktiv/terkepek/mo/kozl.htm1? mapid=ODE001 [Accessed: 29 April 2019] (in Hungarian)

KSH (2018b) "Magyarország helységnévtára" (Detailed Gazetteer of Hungary), [online] Available at: http://www.ksh.hu/apps/hntr. main?p_lang=HU [Accessed: 29 April 2019] (in Hungarian)

Matulin, M., Mrvelj, Š., Jelušić, N. (2014) "Evaluating Public Transport Performances by Utilizing Probe Vehicles", International Journal for Traffic and Transport Engineering, 4(2), pp. 183-193. https://doi.org/10.7708/ijtte.2014.4(2).05

Murray, A. T., Davis, R., Stimson, R. J., Ferreira, L. (1998) "Public transportation access", Transportation Research Part D: Transport and Environment, 3(5), pp. 319-328. https://doi.org/10.1016/S1361-9209(98)00010-8

Murray, A. T. (2001) "Strategic analysis of public transport coverage", Socio-Economic Planning Sciences, 35(3), pp. 175-188. https://doi.org/10.1016/S0038-0121(01)00004-0

Nilsson, J. E. (2015) "Congestion and scarcity in scheduled transport modes", In: Handbook of Research Methods and Applications in Transport Economics and Policy, 1st ed., Edward Elgar Publishing, Cheltenham, UK, pp. 134-153. https://doi.org/10.4337/9780857937933.00014

Pina, V., Torres, L. (2001) "Analysis of the efficiency of local government services delivery. An application to urban public transport", Transportation Research Part A: Policy and Practice, 35(10), pp. 929-944.

https://doi.org/10.1016/S0965-8564(00)00033-1

Preston, J. (2015) "Public transport demand", In: Handbook of Research Methods and Applications in Transport Economics and Policy, 1st ed., Edward Elgar Publishing, Cheltenham, UK, pp. 192-211. https://doi.org/10.4337/9780857937933.00018

Pucher, J., Kurth, S. (1995) "Verkehrsverbund: the success of regional public transport in Germany, Austria and Switzerland", Transport Policy, 2(4), pp. 279-291. https://doi.org/10.1016/0967-070X(95)00022-I
Saif, M. A., Zefreh, M. M., Török, Á. (2019) "Public Transport Accessibility: A Literature Review", Periodica Polytechnica Transportation Engineering, 47(1), pp. 36-43. https://doi.org/10.3311/PPtr.12072

Scheurer, J., Porta, S. (2006) "Centrality and connectivity in public transport networks and their significance for transport sustainability in cities", In: World Planning Schools Congress, Global Planning Association Education Network, Mexico DF, Mexico.

Sienkiewicz, J., Hołyst, J. A. (2005) "Statistical analysis of 22 public transport networks in Poland", Physical Review E, 72(4), Article ID: 046127. https://doi.org/10.1103/PhysRevE.72.046127

Šipuš, D., Abramović, B. (2017) "The Possibility of Using Public Transport in Rural Area", Procedia Engineering, 192, pp. 788-793. https://doi.org/10.1016/j.proeng.2017.06.136

Taylor, P., Hoyler, M. (2000) "The spatial order of European cities under conditions of contemporary globalization", Tijdschrift voor Economische en Sociale Geografie, 91(2), pp. 176-189. https://doi.org/10.1111/1467-9663.00104

Török, Á., Schmalz, A. A. (2018) "Transportation in Brazil: Joinville", Periodica Polytechnica Transportation Engineering, 46(2), pp. $78-81$. https://doi.org/10.3311/PPtr.9869

World Bank (2018) "GDP (current US\$)", [online] Available at: https:// data.worldbank.org/indicator/NY.GDP.MKTP.CD [Accessed: 29 April 2019]

Yatskiv, I., Budilovich, E., Gromule, V. (2017) "Accessibility to Riga Public Transport Services for Transit Passengers", Procedia Engineering, 187, pp. 82-88. https://doi.org/10.1016/j.proeng.2017.04.353

Zhang, J., Li, J., Wu, Y. (2017) "A Study of Metro Organization Based on Multi-objective Programming and Hybrid Genetic Algorithm", Periodica Polytechnica Transportation Engineering, 45(4), pp. 223-229. https://doi.org/10.3311/PPtr.9586 